\title{
Increased ovulation rate in gilts treated with dihydrotestosterone
}

\author{
H. Cárdenas, J. R. Herrick and W. F. Pope \\ Department of Animal Sciences, The Ohio State University, 2029 Coffey Road, \\ Columbus, OH 43210, USA
}

\begin{abstract}
Treatment with testosterone increases ovulation rate in pigs. The present study was conducted to examine the effects of $5 \alpha$-dihydrotestosterone (DHT), a non-aromatizable androgen receptor ligand, on ovulation rate and amounts of androgen receptor and FSH receptor mRNAs in postpubertal gilts. In Expt 1, ovulation rate in response to daily i.m. injections of $0,6,60$ or $600 \mu \mathrm{g}$ DHT $\mathrm{g}^{-1}$ body weight from day 13 of the oestrous cycle (day $0=$ day 1 of oestrus) to the following oestrus increased with each dose of DHT $(P<0.05)$. The mean increase in number of corpora lutea ranged from approximately three to 17 over the three dosages of DHT. In Expt 2, gilts treated daily with $60 \mu \mathrm{g}$ DHT $\mathrm{kg}^{-1}$ body weight during the early follicular phase (from day 13 to day 16), coincident with follicular recruitment, or the late follicular phase (day 17 to oestrus), had higher $(P<0.05)$ rates of ovulation compared with gilts
\end{abstract}

\section{Introduction}

Testosterone and androstenedione serve as intermediaries for the synthesis of oestrogen in ovarian follicles (Peters and McNatty, 1980). Androgens might also exert regulatory effects on follicular development. For example, androgens enhanced the effects of FSH on steroidogenesis in vitro (Armstrong and Dorrington, 1976; Daniel and Armstrong, 1980; Harlow et al., 1986) and results from our laboratory indicated that testosterone administered during the follicular phase increased the number of preovulatory follicles, ovulation rate (number of corpora lutea) and the number of blastocysts in pigs (Cárdenas and Pope, 1994, 1997). More recently, it was demonstrated that androgens enhanced the effects of FSH on DNA synthesis in rat granulosa cells (Bley et al., 1997), stimulated early growth of primate follicles (Vendola et al., 1998), augmented the development of mouse follicles in vitro (Murray et al., 1998) and increased insulin-like growth factor I (IGF-I) and IGF-I receptor mRNAs in primate follicles and oocytes (Vendola et al., 1999a,b).

The use of testosterone in our previous experiments (Cárdenas and Pope, 1994, 1997) raised the question of whether oestradiol or androgen receptor or both mediated the effects of testosterone treatment on ovulation rate. The androgen receptor protein has been located in granulosa cells of small growing follicles and, in lesser amounts, in

Email: cardenas-seijas.2@osu.edu that received vehicle, and were not different from gilts treated with DHT from day 13 to oestrus. Percentage recovery of day 3 embryos was not altered when gilts were treated from day 13 to day 16 or from day 17 to oestrus; however, treatment of gilts with DHT from day 13 to oestrus decreased recovery of day 3 (Expt 1) or day 11 (Expt 2) conceptuses. Daily administration of $6 \mu \mathrm{g}$ DHT $\mathrm{kg}^{-1}$ body weight to gilts from day 13 of the oestrous cycle to the following oestrus (Expt 3) did not affect the relative amounts of androgen receptor $\mathrm{mRNA}$, but increased $(P<0.05)$ the amounts of FSH receptor mRNA in preovulatory follicles as determined by RT-PCR. The results of these experiments indicate that androgens may regulate ovulation rate in gilts. One of the roles of androgens might be regulation of the amounts of FSH receptor mRNA in ovarian follicles. larger follicles of several mammalian species (Tetsuka et al., 1995; Garrett and Guthrie, 1996; Hillier et al., 1997). The mechanisms involved in the effects of testosterone on ovulation rate in pigs are not known and could include ovarian- and gonadotrophin-related factors that influence follicular recruitment and atresia. Follicular atresia in pigs (Guthrie et al., 1995) and other mammals (Kaipia and Hsueh, 1997) occurs primarily through apoptosis. In pigs, follicular recruitment occurs from day 14 to day 16 of the oestrous cycle (Clark et al., 1982; Foxcroft and Hunter, 1985) and appears to be controlled mainly by FSH (Foxcroft and Hunter, 1985). Furthermore, FSH decreases apoptosis in cultured granulosa cells of rats and pigs (Tilly et al., 1991; Chun et al., 1996; Guthrie et al., 1998). In the present experiment, the effects of DHT, a non-aromatizable androgen receptor ligand, on ovulation rate and the relative amounts of FSH receptor and androgen receptor mRNAs in preovulatory follicles of pigs were examined.

\section{Materials and Methods}

Gilts (cross of Yorkshire, Landrace, Duroc and Hampshire from the university herd) were exposed to boars once a day (in the morning) to determine the onset of oestrus (day 0 of the oestrous cycle). Gilts that underwent at least one oestrous cycle were used in the experiments. Testosterone or DHT (Sigma Chemical Co., St Louis, MO) was dissolved in ether and mixed with an appropriate volume of corn oil to make stock solutions. The ether was allowed to evaporate 
at room temperature before the stocks were used for preparation of the doses used in the different experiments. Steroids were administered daily (in the morning) by i.m. (rear leg) injections according to the experimental protocols. Gilts were mated twice to different boars at 8 and $24 \mathrm{~h}$ after the onset of oestrus. All procedures applied to the animals were approved by the College of Agriculture Animal Care and Use Committee.

\section{Experiment 1: response to dose of DHT}

Gilts ( $n=8$ per group) received daily injections of 0 (corn oil), 6, 60 or $600 \mu \mathrm{g}$ DHT kg-1 body weight from day 13 of the oestrous cycle to oestrus to determine the effects of dose of DHT on numbers of ovulations and day 11 blastocysts. The doses of 6, 60 or $600 \mu \mathrm{g}$ DHT were dissolved in 2, 2 and $8 \mathrm{ml}$ of corn oil, respectively. Two millilitres of oil was used with smaller doses of DHT to decrease the amount of oil injected into the animals. Gilts from the control group received daily injections of $8 \mathrm{ml}$ oil. Gilts were mated twice to different boars and ovariohysterectomized on day 11. Corpora lutea were dissected, weighed and counted. The uterus was flushed with $0.9 \%(\mathrm{w} / \mathrm{v}) \mathrm{NaCl}$ to recover the blastocysts, which were counted and examined to assess their developmental stage. Percentage blastocyst recovery was calculated as the proportion of blastocysts relative to the number of corpora lutea.

\section{Experiment 2: effects of period of DHT treatment}

The aim of this experiment was to determine whether DHT treatment during three different stages of the oestrous cycle would affect the ovulation rate in gilts. The intermediate dose of $60 \mu \mathrm{g}$ DHT kg-1, which had a highly significant effect on ovulation rate in Expt 1, was used in Expt 2. Although a lower dose of DHT (6 $\mathrm{g} \mathrm{kg}^{-1}$ body weight) increased ovulation rate after 8 days of administration in Expt 1, its influence on ovulation rate might have been reduced by the shorter duration of treatment (4 days) applied in Expt 2, thereby decreasing our ability to detect the effect of periods of treatment. Gilts ( $n=8$ per group) received daily injections of DHT during the following stages of the oestrous cycle: day 13 to oestrus, day 13 to day 16, or day 17 to oestrus. Control gilts $(n=8)$ received vehicle (corn oil) from day 13 to oestrus. Gilts were mated and then ovariohysterectomized on day 3 . The number of corpora lutea was counted and the oviducts and tips (approximately $15 \mathrm{~cm}$ ) of the uterine horns were flushed to recover the embryos for verification of ovulations and ova pick-up. Embryos were recovered on day 3 instead of day 11 (Expt 1) to minimize the possible influence of the uterus on conceptus survival that was observed in Expt 1.

\section{Experiment 3: effects of androgens on amounts of androgen receptor and FSH receptor $m R N A s$}

The effects of exogenous androgens on the relative amounts of $\mathrm{FSH}$ receptor and androgen receptor mRNAs in preovulatory follicles were determined using semiquantitative RT-PCR. Vehicle (corn oil), $6 \mu \mathrm{g}$ DHT or $6 \mathrm{mg}$ testosterone $\mathrm{kg}^{-1}$ body weight was administered to gilts from day 13 to oestrus $(n=4)$. This dose of androgens was used because it increased ovulation rate and was comparable (based on total body weight) to $1 \mathrm{mg}$ testosterone, which was the best characterized dosage used from day 13 to oestrus in previous experiments (Cárdenas and Pope, 1997). Ovaries were removed surgically approximately $8 \mathrm{~h}$ after the last treatment given on the day of oestrus. The preovulatory LH surge in pigs occurs at about the onset of oestrus (Van de Wiel et al., 1981) and, although not verified, it was assumed that gilts had already had an LH surge before the ovaries were removed. A representative sample of tissue from preovulatory follicles was obtained by carefully dissecting pieces of follicular walls protruding from the surface of the ovary of $5-6$ follicles $\geqslant 8 \mathrm{~mm}$ in diameter, which were then pooled, frozen in liquid nitrogen and stored at $-80^{\circ} \mathrm{C}$. Total cellular RNA was isolated from follicular tissue using the RNeasy kit (Qiagen, Valencia, CA). The purity and integrity of the RNA were verified by calculating the ratio of absorbance at 260 and $280 \mathrm{~nm}$ and by estimating the ratio of the $28 \mathrm{~S}$ and $18 \mathrm{~S}$ rRNA bands, respectively. Concentration of RNA was determined using the absorbance at $260 \mathrm{~nm}$.

RT-PCR was performed using the GeneAmp RNA PCR kit (Roche Molecular Systems, Inc., Branchburg, NJ). Primer pairs spanning at least two exons for androgen receptor were obtained from Butler et al. (1998) and those for FSH receptor and glyceraldehyde-3 phosphate dehydrogenase (GPDH, used as loading control) were constructed based on pig sequences (GenBank accessions: AF025377 for FSH receptor and AF017079 for GPDH; Table 1). Initially, RT-PCR for each of FSH receptor, androgen receptor and GPDH was optimized independently for cycling temperatures and concentrations of primers and magnesium chloride. Additional assays were performed to establish the exponential regions of the amplification curves by sampling reactions every other cycle. Common assay conditions that would work for all three genes were used for performing RT-PCR for FSH receptor, androgen receptor and GPDH simultaneously in a multiplex setting. Authenticity of FSH receptor and GPDH fragments was determined by sequencing the PCR products. The androgen receptor product was cloned into the pCR2.1 vector (Invitrogen, San Diego, CA) and sequenced. Results were compared with sequences at the GenBank using the BLAST software from the National Center for Biotechnology Information web page. The putative androgen receptor fragment had $92 \%$ sequence identities with the androgen receptors of sheep, dogs, humans and other mammals, and 99\% with a recently released pig androgen receptor sequence (GenBank accession AF202775).

First strand cDNA was synthesized using $0.5 \mu \mathrm{g}$ total RNA and Maloney murine leukaemia virus reverse transcriptase primed with random hexamers. Tubes were incubated for $10 \mathrm{~min}$ at room temperature, for $30 \mathrm{~min}$ at $42^{\circ} \mathrm{C}$, for $5 \mathrm{~min}$ at $99^{\circ} \mathrm{C}$ and then cooled to $5^{\circ} \mathrm{C}$. Duplicate 
Table 1. Primers used for RT-PCR of the pig androgen receptor, FSH receptor and glyceraldehyde-3 phosphate dehydrogenase (GPDH) and sizes of amplified fragments

\begin{tabular}{llc}
\hline Gene & \multicolumn{1}{c}{ Primer type and sequence (5' to 3') } & Fragment size (bp) \\
\hline Androgen receptor & $\begin{array}{l}\text { Sense: CACATTGAAGGCTATGAGTG } \\
\text { Antisense: CCCATCCAGGAGTACTGAAT } \\
\text { FSH receptor }\end{array}$ & $\begin{array}{l}\text { Sense: AGCCTCTGGACCAGTCATTC } \\
\text { Antisense: CACCATCTTCTGCCAGAGAC } \\
\text { GPDH }\end{array}$ \\
& $\begin{array}{l}\text { Sense: CCTGGCCAAGGTCATCCATG } \\
\text { Antisense: CCACCACCCTGTTGCTGTAG }\end{array}$ & 508 \\
\end{tabular}

Table 2. Effects of dose of $5 \alpha$-dihydrotestosterone (DHT) on number of corpora lutea, number of day 11 blastocysts, duration of the oestrous cycle and corpora lutea mass in gilts

\begin{tabular}{lccccc}
\hline $\begin{array}{l}\mathrm{DHT}\left(\mu \mathrm{g} \mathrm{kg}{ }^{-1}\right. \\
\text { body weight)* }^{*}\end{array}$ & $\begin{array}{c}\text { Number of } \\
\text { corpora lutea }\end{array}$ & $\begin{array}{c}\text { Number of } \\
\text { blastocysts }^{\dagger}\end{array}$ & $\begin{array}{c}\text { Blastocyst } \\
\text { recovery }(\%)^{+}\end{array}$ & $\begin{array}{c}\text { Oestrous } \\
\text { cycle (days) }\end{array}$ & $\begin{array}{c}\text { Corpora lutea } \\
\text { mass (mg) }\end{array}$ \\
\hline 0 & $17.4 \pm 0.3^{\mathrm{a}}$ & $15.9 \pm 0.5$ & $91.3 \pm 2.4$ & $19.5 \pm 0.4^{\mathrm{a}}$ & $400 \pm 29^{\mathrm{a}}$ \\
6 & $20.3 \pm 0.9^{\mathrm{b}}$ & $9.4 \pm 3.2$ & $46.5 \pm 14.7$ & $19.6 \pm 0.4^{\mathrm{a}}$ & $412 \pm 27^{\mathrm{a}}$ \\
60 & $27.9 \pm 1.3^{\mathrm{c}}$ & $0.3 \pm 0.7$ & $1.1 \pm 1.1$ & $20.6 \pm 0.4^{\mathrm{a}}$ & $360 \pm 23^{\mathrm{a}}$ \\
600 & $34.6 \pm 1.8^{\mathrm{d}}$ & $0 \pm 0$ & $0 \pm 0$ & $20.3 \pm 0.4^{\mathrm{a}}$ & $345 \pm 33^{\mathrm{a}}$ \\
\hline
\end{tabular}

${ }^{*} n=8$ per group except for gilts treated with $600 \mu \mathrm{g}$ DHT kg-1 body weight, $n=6$ for oestrous cycle data (onset of oestrus was not clear in two gilts) and $n=3$ for corpora lutea mass (five gilts had fluid-filled corpora lutea).

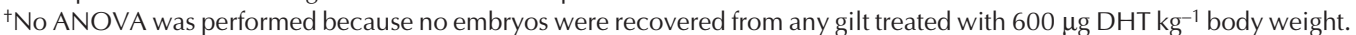

a-d Means within a column lacking a common superscript are significantly different $(P<0.05)$.

PCR assays were performed using aliquots (equivalent to $0.25 \mu \mathrm{g}$ total RNA) of the reverse transcription mixtures, Taq DNA polymerase, $1.5 \mathrm{mmol} \mathrm{MgCl}_{2} \mathrm{I}^{-1}$ and $0.3 \mu \mathrm{mol} \mathrm{I}^{-1}$ of each primer. Concentrations of other components were those given by the kit manufacturer. Tubes were incubated for $1 \mathrm{~min}$ at $95^{\circ} \mathrm{C}$ and subjected to cycles of $1 \mathrm{~min}$ at $95^{\circ} \mathrm{C}$, $45 \mathrm{~s}$ at $55^{\circ} \mathrm{C}$ and $2 \mathrm{~min}$ at $72^{\circ} \mathrm{C}$. The number of cycles was 25 for $\mathrm{FSH}$ receptor and androgen receptor, and 20 for GPDH. As fewer cycles were used for GPDH amplification, primers for GPDH were added during the denaturation step of cycle number 6 . Reaction mixtures were covered with mineral oil to avoid evaporation during this step. Sample incubation finished with a $7 \mathrm{~min}$ extension at $72^{\circ} \mathrm{C}$ followed by cooling to $5^{\circ} \mathrm{C}$. A set of negative controls was included in which no reverse transcriptase was used. Products were analysed by electrophoresis on a $1.5 \%(\mathrm{w} / \mathrm{v})$ agarose gel, visualized by ethidium bromide staining and photographed using Polaroid film T57. Pictures were scanned and densitometric analysis of cDNA bands was performed using ImageJ (National Institute of Health; http://rsb.info.nih.gov/ ij/). No bands were detected in negative controls. Staining intensity of GPDH was not influenced by treatment. The relative amount of $\mathrm{FSH}$ receptor or androgen receptor mRNA was defined as the ratio of densitometric values of $\mathrm{FSH}$ receptor or androgen receptor to GPDH. The FSH receptor bands in this study represent the full-length $\mathrm{FSH}$ receptor and isoform $\mathrm{FSH}$ receptor 2 but not $\mathrm{FSH}$ receptor 3 , as described by Touyz et al. (2000). The average coefficients of variation of androgen receptor and $\mathrm{FSH}$ receptor determinations in two separate PCR assays were 11.6 and $11.2 \%$, respectively.

\section{Statistical analyses}

Data were analysed by one-way ANOVA for a completely randomized design using a computer program (SPSS, 1999). Variance of number of corpora lutea in Expt 1 was heterogeneous, so data were transformed to logarithms for use in ANOVA. Post-hoc comparisons of means were performed using protected LSD tests.

\section{Results}

\section{Experiment 1}

Daily administration of DHT, from day 13 of the oestrous cycle to oestrus, influenced $(P<0.001)$ ovulation rate in cyclic gilts. The number of corpora lutea increased by approximately 3, 10 and 17 in gilts receiving 6,60 or $600 \mu \mathrm{g}$ DHT $\mathrm{kg}^{-1}$ body weight, respectively, compared with gilts receiving vehicle (Table 2 ).

Most of the corpora lutea in five of the eight gilts that received the highest dose of DHT had fluid-filled cavities. The other three gilts in this group and gilts that received lower doses of DHT or vehicle had corpora lutea that looked normal and that did not differ in mass (Table 2). Number and rate of recovery of day 11 blastocysts were decreased markedly in gilts that received DHT (Table 2). Low rates of blastocyst recovery were associated with 
Table 3. Effects of $5 \alpha$-dihydrotestosterone (DHT) treatment during different periods of the oestrous cycle on numbers of corpora lutea and characteristics of day 3 embryos in gilts

\begin{tabular}{|c|c|c|c|c|}
\hline $\begin{array}{l}\text { DHT treatment } \\
\text { (day of cycle)* }^{*}\end{array}$ & $\begin{array}{c}\text { Number of } \\
\text { corpora lutea }\end{array}$ & $\begin{array}{c}\text { Number of } \\
\text { embryos }^{\dagger}\end{array}$ & $\begin{array}{c}\text { Embryo } \\
\text { recovery }(\%)^{\dagger}\end{array}$ & $\begin{array}{c}\text { Embryos with } \geqslant 2 \\
\text { blastomeres }(\%)^{+}\end{array}$ \\
\hline Vehicle & $19.5 \pm 1.2^{\mathrm{a}}$ & $15.5 \pm 1.7^{\mathrm{a}}$ & $79.3 \pm 5.7^{a}$ & $81.1 \pm 10.2^{\mathrm{a}}$ \\
\hline Day 13 to oestrus & $26.6 \pm 1.2^{b}$ & $15.6 \pm 2.0^{\mathrm{ab}}$ & $60.8 \pm 6.5^{b}$ & $57.3 \pm 11.8^{\mathrm{a}}$ \\
\hline Day 13 to day 16 & $26.1 \pm 1.2^{b}$ & $20.4 \pm 1.7^{b c}$ & $77.8 \pm 5.7^{a b}$ & $94.9 \pm 10.2^{\mathrm{a}}$ \\
\hline Day 17 to oestrus & $23.9 \pm 1.2^{b}$ & $21.7 \pm 1.9^{c}$ & $89.4 \pm 6.1^{\mathrm{a}}$ & $83.9 \pm 10.9^{a}$ \\
\hline
\end{tabular}

*Dose was $60 \mu \mathrm{g} \mathrm{kg}^{-1}$ body weight per day. Control gilts received vehicle from day 13 to oestrus.

${ }^{\dagger}$ Only gilts from which embryos were recovered were included ( $n=8$ for vehicle and day 13 to day $16, n=7$ for day 17 to oestrus and $n=6$ for day 13 to oestrus).

${ }^{a-c}$ Means within a column lacking a common superscript are significantly different $(P<0.05)$.
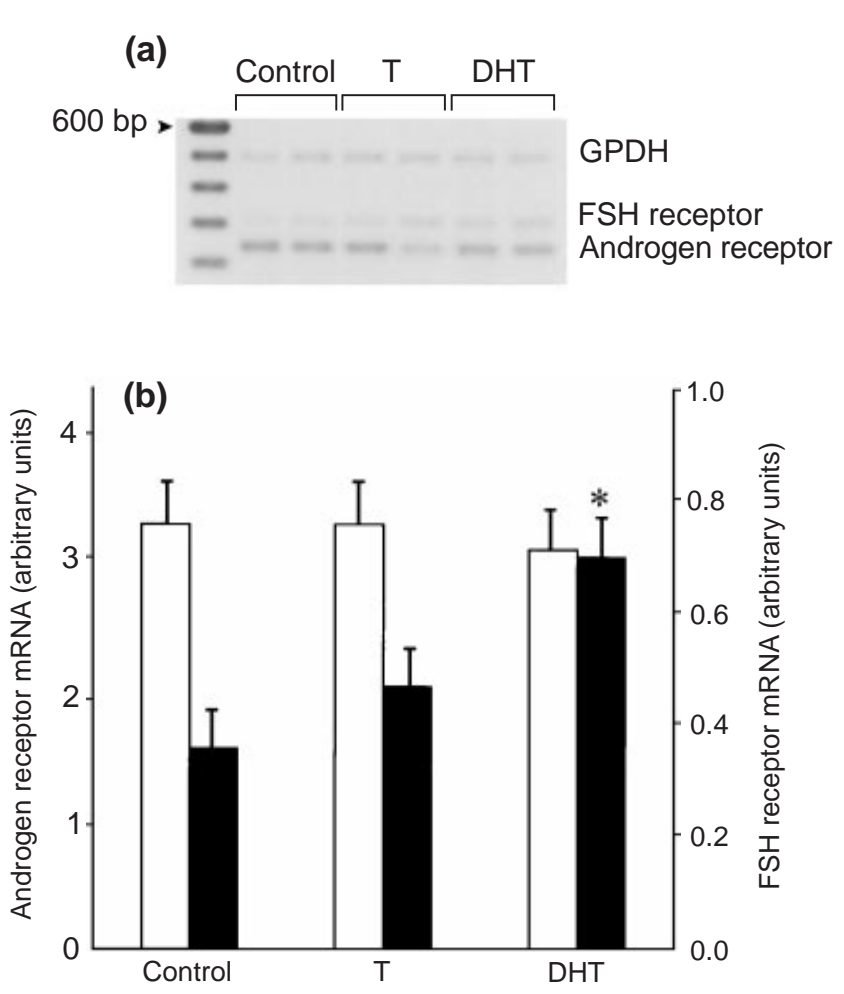

Fig. 1. (a) Multiplex RT-PCR of androgen receptor, FSH receptor and glyceraldehyde phosphate dehydrogenase $(\mathrm{GPDH})$ in preovulatory follicles of gilts ( $n=4$ per group) treated daily with $6 \mu \mathrm{g}$ testosterone (T) or $5 \alpha$-dihydrotestosterone (DHT) $\mathrm{kg}^{-1}$ body weight, or vehicle (control) from day 13 of the oestrous cycle to oestrus. The RT-PCR products were stained with ethidium bromide (negative image) in representative samples. The left lane is a 100 bp DNA ladder. (b) Relative amounts of androgen receptor ( $\square$ ) and FSH receptor $(\square)$ mRNAs obtained by densitometric analysis of RT-PCR products. Values for androgen receptor and FSH receptor were corrected for loading using GPDH. *Asterisk indicates significant difference from control and testosterone value for $\mathrm{FSH}$ receptor mRNA $(P<0.05)$. opaque uterine flushings and were observed in gilts that received $600 \mu \mathrm{g}$ DHT kg-1 body weight and in $50 \%$ of the gilts that received $60 \mu \mathrm{g}$ DHT $\mathrm{kg}^{-1}$ body weight. All of the blastocysts recovered were spherical and $>1 \mathrm{~mm}$ in diameter, which is the stage expected by day 11 of gestation in pigs. Administration of DHT did not influence the duration of the oestrous cycle. Mean duration of the oestrous cycle was 20 days (Table 2) and, therefore, treatments were given for an average of 8 days.

\section{Experiment 2}

The number of corpora lutea in gilts treated with daily doses of $60 \mu \mathrm{g}$ DHT kg-1 body weight from day 13 of the oestrous cycle to oestrus, from day 13 to day 16, or from day 17 to oestrus was higher $(P<0.05)$ than in gilts that received vehicle. However, the number of corpora lutea was not different among gilts that received DHT from day 13 to oestrus, from day 13 to day 16, or from day 17 to oestrus (Table 3). The total number of embryos in gilts treated with DHT from day 13 to oestrus was not different from the total number in gilts treated from day 13 to day 16 or in vehicletreated gilts, but was lower $(P<0.05)$ compared with gilts treated with DHT from day 17 to oestrus (Table 3$)$. The percentage recovery of day 3 embryos was lower $(P<0.05)$ in gilts treated from day 13 of the oestrous cycle to oestrus than in gilts that received vehicle or in gilts treated from day 17 to oestrus (Table 3). Treatment with DHT did not affect the proportion of embryos with two or more blastomeres, although a numerical decrease of $23.7 \%$ was observed in gilts treated from day 13 to oestrus compared with controls (Table 3).

\section{Experiment 3}

The relative amounts of androgen receptor mRNA in preovulatory follicles were not influenced by daily treatment with $6 \mu \mathrm{g} \mathrm{kg}^{-1}$ body weight of testosterone or DHT from day 13 to oestrus (Fig. 1). Gilts treated with DHT had higher $(P<0.05)$ amounts of FSH receptor mRNA compared with those treated with testosterone or vehicle. Amounts of $\mathrm{FSH}$ receptor in preovulatory follicles of gilts 
treated with testosterone or vehicle were not significantly different (Fig. 1).

\section{Discussion}

This is thought to be the first report of an increase in ovulation rate produced by administration of DHT in any species. Although Cardenas and Pope $(1994,1997)$ reported that ovulation rate increased in gilts treated with testosterone, the effects of DHT in the present study indicate that androgen receptor might mediate, at least in part, these effects. DHT is an androgen receptor ligand that cannot be aromatized into oestrogens (Wilson, 1975) and is synthesized from testosterone in tissues containing $5 \alpha$-reductase, predominantly in males. The increases in ovulation rate induced by DHT were highly dependent on dose. The responses of ovulation rate to DHT were greater that those obtained previously using similar doses of testosterone (Cárdenas and Pope, 1997), which might be attributed to the higher androgenic activity of DHT relative to testosterone (Grino et al., 1990).

The effects of DHT on follicular development in vivo have been examined in other species. Daily injections of $1 \mathrm{mg} \mathrm{DHT} \mathrm{kg}{ }^{-1}$ body weight given to rats after eCG treatment decreased ovulation rate; however, smaller doses had no effects (Conway et al., 1990). In rhesus monkeys, administration of $145 \mu \mathrm{g}$ DHT kg-1 per day increased the number of small follicles but did not alter the number of preovulatory follicles (Vendola et al., 1998). It has been proposed that androgens are regulators of early follicular development but serve mainly as substrates for oestrogens during late development (Tetsuka and Hillier, 1997). However, there appear to be differences between species, as our results with pigs indicate that androgens might affect late follicular development.

The possibility that the effects of DHT on ovulation rate could be due to actions occurring during follicular recruitment or after recruitment was examined in Expt 2. Treatment during all three periods (from day 13 of the oestrous cycle to oestrus (entire follicular phase), from day 13 to day 16 (recruitment), or from day 17 to oestrus (after recruitment)) increased ovulation rate. These results indicate that androgens might regulate at least one process associated with ovulation rate that is functional both during and after recruitment. In gilts, most recruited follicles become atretic before reaching $6 \mathrm{~mm}$ in diameter (Grant et al., 1989), indicating that atresia is a relatively frequent event during the early follicular phase and decreases during oestrus. DHT might have inhibited atresia among recruited follicles; however, it is not known whether DHT also increased the total number of recruited follicles when administered from day 13 to oestrus or from day 13 to day 17 . These hypotheses need to be tested in subsequent experiments.

Factors that allow androgens to influence ovulation rate are difficult to define. It is possible that DHT could have influenced certain ovarian factors or altered gonadotrophin secretion in such a way as to increase ovulation rate. Induc- tion of superovulation by FSH or eCG significantly decreased when given after day 16 relative to day 15 or day 16 (Phillippo, 1968). However, ovulation rate was increased in gilts receiving androgen treatment after day 16 (DHT from day 17 to oestrus in the present study, or testosterone on days 17 and 18 in the study of Cárdenas and Pope, 1994). These relationships indicated a possible role for androgens in the ovary. Although experiments in female rats demonstrated that DHT had no effect on plasma concentrations of LH or FSH (Conway et al., 1990), the effects of androgens on gonadotrophin secretion in pigs cannot be excluded and also require further study.

FSH is a major regulator of follicular development and inhibits apoptosis in pig granulosa cells (Guthrie et al., 1998). As a result of these effects of FSH, we examined whether androgen treatments that increased ovulation rate also altered the relative amounts of FSH receptor mRNA in preovulatory follicles. The results of Expt 3 demonstrate that gilts treated with DHT have almost double the amount of $\mathrm{FSH}$ receptor mRNA in preovulatory follicles compared with control gilts. The less active androgen, testosterone, did not significantly alter FSH receptor mRNA content, perhaps because $\mathrm{FSH}$ receptor $\mathrm{mRNA}$ is significantly downregulated in preovulatory follicles at oestrus (Yuan et al., 1996; Liu et al., 1998). Although it remains to be confirmed whether the increase in the amount of $\mathrm{FSH}$ receptor mRNA induced by DHT results in similar changes in FSH receptor protein, this finding indicates that androgens might be able to upregulate $\mathrm{FSH}$ receptor and perhaps enhance the ability of follicles to respond to FSH. Positive actions of testosterone on the amounts of FSH receptor mRNA in primary follicles of primates have also been observed (Weil et al., 1999).

Direct regulation of the $\mathrm{FSH}$ receptor gene by androgen receptor might not be plausible because an androgen response element on the $\mathrm{FSH}$ receptor gene promoter has not been identified. It is not known whether androgen receptor influences FSH receptor mRNA stability. Homologous regulation of $\mathrm{FSH}$ receptor by $\mathrm{FSH}$ has been reported in pig granulosa cells in vitro and the results depended on the dose of FSH used: small doses of FSH increased FSH receptor mRNA content, whereas larger doses had the opposite effect (Sites et al., 1994; Murphy and Dobias, 1999). In the present study, relatively high amounts of androgen receptor mRNA were detected by RT-PCR in preovulatory follicles. Little is known about the regulation of androgen receptor in the ovary and the results vary depending on the species or system used. In one experiment conducted in primates, testosterone increased androgen receptor mRNA in granulosa cells of periantral and small antral follicles (Weil et al., 1998). When cultured rat granulosa cells were treated with DHT, androgen receptor mRNA content decreased, and this effect was reversed by treatment with FSH (Tetsuka and Hillier, 1996). In the present experiment, neither DHT nor testosterone influenced the amount of androgen receptor mRNA in pig preovulatory follicles.

Relatively high doses or long duration of $\mathrm{DHT}$ treatment 
were detrimental to conceptus survival and, apparently, to uterine function. In a previous experiment, daily treatment with $1 \mathrm{mg}$ testosterone from day 13 to oestrus increased ovulation rate and survival of day 11.5 blastocysts (Cárdenas and Pope, 1997). Using $60 \mu \mathrm{g}$ DHT kg-1 body weight and reducing the duration of treatment from 8 to 3-4 days in the present study (Expt 2) resulted in an increased ovulation rate without altering embryonic recovery or cleavage stage by day 3. Although these results indicate that conceptus survival by day 11 may be influenced by attenuation of uterine function after overexposure to DHT, more studies are needed to identify the factors that influence conceptus survival in DHT- and testosterone-treated gilts. It is possible that increased oestradiol content after testosterone administration (Cárdenas and Pope, 1994) might contribute to maintenance of a hormonal balance necessary for normal uterine function, which might not occur with DHT administration.

In conclusion, the results of the present study indicate that androgens might have regulatory functions during late follicular development in pigs that are related to ovulation rate and regulation of $\mathrm{FSH}$ receptor $\mathrm{mRNA}$.

Salaries and research support were provided by State and Federal funds appropriated to The Ohio Agricultural Research and Development Center and The Ohio State University. Manuscript no 10-01AS.

\section{References}

Armstrong DT and Dorrington JH (1976) Androgens augment FSH-induced progesterone secretion by cultured granulosa cells Endocrinology $\mathbf{9 9}$ $1411-1414$

Bley MA, Saragueta PE and Lino Baranao J (1997) Concerted stimulation of granulosa cell deoxyribonucleic acid synthesis by sex steroids and follicle-stimulating hormone Journal of Steroid Biochemistry and Molecular Biology 62 11-19

Butler CM, Harry JL, Deakin JE, Cooper DW and Renfree MB (1998) Developmental expression of the androgen receptor during virilization of the urogenital system of a marsupial Biology of Reproduction 59 725-732

Cárdenas H and Pope WF (1994) Administration of testosterone during the follicular phase increased the number of corpora lutea in gilts Journal of Animal Science 72 2930-2935

Cárdenas H and Pope WF (1997) Administration of testosterone from day 13 of the estrous cycle to estrus increased the number of corpora lutea and conceptus survival in gilts Journal of Animal Science 75 202-207

Chun SY, Eisenhauer KM, Minami S, Billig H, Perlas E and Hsueh JW (1996) Hormonal regulation of apoptosis in early antral follicles: folliclestimulating hormone as a major survival factor Endocrinology 137 1447-1456

Clark JR, Brazier SG, Wiginton LM, Stevenson GR and Tribble LF (1982) Time of ovarian follicle selection during the porcine estrous cycle Theriogenology 18 697-709

Conway BA, Mahesh VB and Mills TM (1990) Effect of dihydrotestoterone on the growth and function of ovarian follicles in intact immature female rats primed with PMSG Journal of Reproduction and Fertility 90 267-277

Daniel SAJ and Armstrong DT (1980) Enhancement of follicle-stimulating hormone-induced aromatase activity by androgens in cultured rat granulosa cells Endocrinology 107 1027-1033

Foxcroft GR and Hunter MG (1985) Basic physiology of follicular maturation in the pig Journal of Reproduction and Fertility Supplement $331-19$
Garrett WM and Guthrie HD (1996) Expression of androgen receptors and steroidogenic enzymes in relation to follicular growth and atresia following ovulation in pigs Biology of Reproduction 55 949-955

Grant SA, Hunter MG and Foxcroft GR (1989) Morphological and biochemical characteristics during ovarian follicular development in the pig Journal of Reproduction and Fertility 86 171-183

Grino PB, Griffin JE and Wilson JD (1990) Testosterone at high concentrations interacts with the human androgen receptor similarly to dihydrotestosterone Endocrinology 126 1165-1172

Guthrie HD, Grimes RW, Cooper BS and Hammond JM (1995) Follicular atresia in pigs: measurement and physiology Journal of Animal Science 73 2834-2844

Guthrie HD, Garrett WM and Cooper BS (1998) Follicle-stimulating hormone and insulin-like growth factor-I attenuate apoptosis in cultured porcine granulosa cells Biology of Reproduction 58 390-396

Harlow CR, Hillier SG and Hodges JK (1986) Androgen modulation of follicle-stimulating hormone-induced granulosa cell steroidogenesis in the primate ovary Endocrinology 119 1403-1405

Hillier SG, Tetsuka M and Fraser HM (1997) Location and developmental regulation of androgen receptor in the primate ovary Human Reproduction 12 107-111

Kaipia A and Hsueh AJW (1997) Regulation of ovarian follicle atresia Annual Review of Physiology 59 349-363

Liu JK, Aronow BJ, Witte DP, Pope WF and La Barbera AR (1998) Cyclic and maturation-dependent regulation of follicle-stimulating hormone receptor and luteinizing hormone receptor messenger ribonucleic acid expression in the porcine ovary Biology of Reproduction 58 648-658

Murphy B and Dobias M (1999) Homologous and heterologous ligands down-regulate follicle stimulating hormone receptor mRNA in porcine granulosa cells Molecular Reproduction and Development 53 198-207

Murray AA, Gosden RG, Allison V and Spears N (1998) Effect of androgens on the development of mouse follicles growing in vitro. Journal of Reproduction and Fertility 113 27-33

Peters H and McNatty KP (1980) The Ovary Granada Publishing, London

Phillippo M (1968) Superovulation in the pig Advances in Reproductive Physiology 3 147-166

Sites CK, Patterson K, Jamison CS, Friezner Degen SJ and LaBarbera AR (1994) Follicle-stimulating hormone (FSH) increases FSH receptor messenger ribonucleic acid while decreasing FSH binding in cultured porcine granulosa cells Endocrinology 134 411-417

SPSS Inc. (1999) SPSS for Windows release 9.0.0 Chicago

Tetsuka M and Hillier SG (1996) Androgen receptor gene expression in rat granulosa cells: the role of follicle-stimulating hormone and steroid hormones Endocrinology 137 4392-4397

Tetsuka M and Hillier SG (1997) Differential regulation of aromatase and androgen receptor in granulosa cells Journal of Steroid Biochemistry and Molecular Biology 61 233-239

Tetsuka M, Whitelaw PF, Bremmer WJ, Millar MR, Smyth CD and Hillier SG (1995) Developmental regulation of androgen receptor in the rat ovary Journal of Endocrinology 145 535-543

Tilly JL, Kowalski KI, Johnson AL and Hsueh AJ (1991) Involvement of apoptosis in ovarian follicular atresia and postovulatory regression Endocrinology 129 2799-2801

Touyz RM, Jiang L and Sairam MR (2000) Follicle-stimulating hormone mediated calcium signaling by the alternatively spliced growth factor type I receptor Biology of Reproduction 62 1067-1074

Van de Wiel DFM, Erkens J, Koops W, Vos E and Van Landeghem AAJ (1981) Periestrous and midluteal time courses of circulating LH, FSH, prolactin, estradiol- $17 \beta$ and progesterone in the domestic pig Biology of Reproduction 24 223-233

Vendola K, Zhou J, Adesanya OO, Weil SJ and Bondy CA (1998) Androgens stimulate early stages of follicular growth in primate ovary Journal of Clinical Investigations $1012622-2629$

Vendola K, Zhou J, Wang J, Famuyiwa OA, Bievre M and Bondy CA (1999a) Androgens promote oocyte insulin-like growth factor I expression and initiation of follicle development in the primate ovary Biology of Reproduction 61 353-357

Vendola K, Zhou J, Wang J and Bondy CA (1999b) Androgens promote insulin-like growth factor-I and insulin-like growth factor-I receptor 
gene expression in the primate ovary Human Reproduction 14 2328-2332

Weil SJ, Vendola K, Zhou J, Adesanya OO, Wang J and Okafor J (1998) Androgen receptor gene expression in the primate ovary: cellular localization, regulation and functional correlations Journal of Clinical Endocrinology and Metabolism 83 2479-2485

Weil SJ, Vendola K, Zhou J and Bondy CA (1999) Androgen and folliclestimulating hormone interactions in primate ovarian follicle development Journal of Clinical Endocrinology and Metabolism 84 2951-2956

Wilson JD (1975) Metabolism of testicular androgens. In Handbook of Physiology, Section 7, Endocrinology, Volume V, Male Reproductive
System pp 491-508 Eds RO Greep and EB Astwood. American Physiological Society, Washington, DC

Yuan W, Lucy WC and Smith MF (1996) Messenger ribonucleic acid for insulin-like growth factors-I and -II, insulin-like growth factor-binding protein-2, gonadotropin receptors, and steroidogenic enzymes in porcine follicles Biology of Reproduction 55 1045-1054

Received 10 July 2001.

First decision 10 September 2001.

Final revision received 17 December 2001.

Accepted 20 December 2001. 